lating mechanism can be introduced to permit a stable point on the left side of the hump.

The absence of a stable point on the left side of the curve helps to explain why cooperation among organisms is often overlooked. The important question arises : why is cooperation so widely distributed in the living kingdoms even though populations are rarely found in the density range corresponding to predominantly cooperative interaction? It is suggested that the presence of cooperation in a species has the function of raising the density of the stable point thus giving a species an edge in competition with other species. In terms of the equation above, the cooperative term illustrated in Figure 3B when added to the remainder of the equation in Figure $3 \mathrm{~A}$ produces a curve in Figure 2 whose stable point is shifted to the right. Thus, other things being equal, cooperative animals have higher densities in their stable population levels than non-cooperative animals. But in all cases, the stable point is characterized by an excess of disoperative competition over cooperation. The intraspecific cooperative effect above may be either linear or a

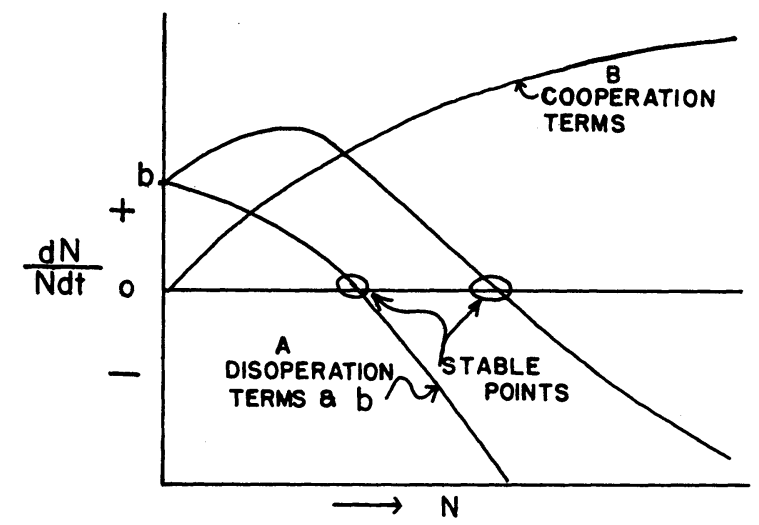

FIG. 3. Survival curve and components for a species with a survival rate that is positive at minimum densities. more complex function such as the second power term suggested by Hutchinson (1947) for social animals.

In man's evolution, we have apparently had continual shifting of the stable point to the right as man's cooperation increased. The great question before us all is not how to increase cooperation or how to avoid the inevitable disoperation but what form of disoperation will ultimately determine our stable point and at what density will this take place.

\section{REFERENCES}

Allee, W. C. 1931. Animal aggregations. A study in general sociology. Univ. of Chicago Press, Chicago. $431 \mathrm{p}$.

1940. Concerning the origin of sociality in animals. Scientia, 1940: 154-160.

- 1951. Cooperation among animals with human implications. Schuman, New York. 233 p.

Allee, W. C., A. E. Emerson, O. Park, T. Park, and K. P. Schmidt. 1949. Principles of animal ecology. Saunders, Phila. 837 p.

Gause, G. F. 1935. Verifications experimentales de la theorie mathematique de la lutte pour la vie. Paris. Actualites scientifiques et industrielles. 277 p.

Holmes, S. J. 1948. The principle of stability as a cause of evolution. A review of some theories. Quart. Rev. Biol. 23 : 324-332.

Hutchinson, G. E. 1947. A note on the theory of competition between two social species. Ecology 28 : 319321.

Ludwig, Wilhelm, and Charlotte Boost. 1939. Über das Wachstum von Protisten Populationen und den allelokatalytischen Effekt. Archiv Protistenkunde 92 : 453-484.

Odum, H. T. 1951. The stability of the world strontium cycle. Science 114 : 407-411.

Department of Biology,

Howard T. Odum

W. C. Allee

UNIVERSITY OF FLORIDA,

Gainesville, Florida

\title{
AN EARLY VIEW OF THE RELATION BETWEEN PLANT DISTRIBUTION AND ENVIRONMENTAL FACTORS
}

A feature of ecology in recent years has been the drift away from mono-climax concepts of vegetation and toward a factorial approach, which emphasizes that plant distribution is conditioned by interactions between several environmental factors capable of independent variation (Cain 1947, Major 1951, Billings 1952). Modern ecologists may, therefore, be interested to learn of a parallel situation existing in Britain over a century ago.

During the early part of the nineteenth century a number of articles were published ascribing differences in plant distribution mainly to single factors, such as differences in rocks or climate. In an attempt to reconcile the various opinions on this matter, $H$. C. Watson published in 1833 a paper entitled "Observations on the Affinities between Plants and subjacent Rocks," where he stated: - "It is ... necessary that all conditions of vegetation distribution be studied in connection. He who neglects any, will so far fail in his generalizations." After a brief illustration of this point of view, he proceeded to a series of conclusions concerning the factors controlling plant distribution. Since these anticipate present-day principles of plant geography and ecology, it may be worthwhile to quote them in full, as follows:-

"I. The principal conditions of vegetable distribution should be arranged in the following order; the firstnamed being of greater sway than those which succeed, and consequently a small difference in the former operating more change than a great dissimilarity in the latter:-1. Temperature; 2. Moisture; 3. Configuration of surface (chiefly with relation to shelter and exposure); 4. The mechanical and chemical properties of the surface soil; 5. The mechanical and chemical properties of the subjacent rocks.

"II. The combined influence of these, with some minor conditions, determines the flora and vegetation of countries.

"III. As to comparative influence, these conditions are not always in equal ratio or proportion; but, when the 
more potent condition or affinity is in its full play, the feebler one is less apparent; and vice versa. Thus, when the temperature is best suited to any given species, soil is of little moment; but when the temperature barely suffices, then soil may determine even the existence of the species.

"IV. Comparing these conditions with each other, the influence of temperature (being less local) is chiefly shown in the flora of a country; while other conditions (often partial in their sway) may not at all affect the flora of a considerable tract, and yet greatly modify its vegetation; the latter term having reference to the comparative prevalence, the former to the mere existence, of the species.

"V. Comparing one species with another, some are more influenced by one, some by another of the above conditions. Some, for example, have a wide range of temperature, others are indifferent to soil or moisture.

"VI. With regard to subjacent rocks, their influence is so frequently veiled by the other conditions, that for the most part the flora of a country is not obviously affected thereby, though the vegetation of small tracts may evidently betray it."

\section{REFERENCES}

Billings, W. D. 1952. The environmental complex in relation to plant growth and distribution. Quart. Rev. Biol. 27 : 251-265.

Cain, S. A. 1947. Characteristics of natural areas and factors in their development. Ecological Monog. 17: $185-200$.

Major, J. 1951. A functional, factorial approach to plant ecology. Ecology 32: 392-412.

Watson, H. C. 1833. Observations on the affinities between plants and subjacent rocks. The Magazine of Natural History 6: 424-427. (This journal was begun by J. C. Loudon, and is continued today as The Annals and Magazine of Natural History).

\section{Botany Department, UNIVERSity COLlEGE, LONDON, ENGLAND}

Eville Gorham

\section{THE OCCURRENCE OF A MAYFLY NYMPH IN BRACKISH WATER}

Circumstantial evidence has been available for some time indicating that the nymphs of Callibaetis floridanus Banks may inhabit brackish water (Berner 1950); however, no salinity determinations were made to substantiate this evidence. In 1949, the senior investigator collected nymphs of this species of mayfly from around the roots of the red mangrove, Rhizophora mangle L., south of Homestead, Florida. Because of the flooded conditions in the Florida Everglades, the water around the tree at that time was definitely fresh.

The junior investigator, while studying the insect fauna of Homosassa Springs, which empties into the Gulf of Mexico north of Tampa, Florida, found that the nymphs of this species were present in water which appeared to be definitely brackish. Further investigation and analysis of the water proved that the insect can tolerate rather high salinities.

The collecting stations from which the nymphs came are approximately one mile inland from the Gulf and are subject to tidal fluctuations. At low tide, chloride values in parts per thousand at the collecting sites were 2.13 (3.92 total salinity) and at three hours past high tide 4.43 (8.15 total salinity). It is estimated that at the peak of high tide the salinity must be somewhere near
10 parts per thousand. Dissolved oxygen ranged from a minimum of 4.62 to a high of 7.02 parts per million.

The nymphs were found on the leaves of the aquatic plants Potomogeton pectinatus L. and Vallisneria neotropicalis M.-V. No other mayfly species were encountered although nymphs of the damselflies Ischnura ramburii (Selys), Enallagma durum (Hagen) and E. pollutum (Hagen), larvae of Tendipedidae and Heleidae, and the water striders Trochopus plumbeus (Uhler), Mesovelia mulsanti White, Trepobates floridensis Drake and Harris, and Rheumatobates temuipes Meinert were found associated with the mayfly nymphs.

\section{REFERENCE}

Berner, Lewis. 1950. The mayflies of Florida. Univ. of Fla. Studies, Biol. Sci. Series 4 : 1-267.

\section{LEWIS BERNER William C. Sloan ${ }^{1}$}

Department of Biology,

UNIVERSITY OF FLORIDA, Gainesville. Florida

\footnotetext{
1 The studies of the junior investigator were aided by a contract between the Office of Naval Research, Department of the Navy, and the University of Florida (NR 163-106).
} 